\title{
Российский Север \\ в условиях глобальной неолиберальной политики: преодоление пространственного неравенства или вытеснение?'
}

\author{
Т.С. ЛЫТКИНА*, А.В. СМИРНОВ**
}

\begin{abstract}
*Татьяна Степановна Лыткина - кандидат социологических наук, старший научный сотрудник, Институт социально-экономических и энергетических проблем Севера Коми научного центра Уральского отделения Российской академии наук. Адрес: 167982, Сыктывкар, ул. Коммунистическая, д. 26. E-mail: tlytkina@yandex.ru **Андрей Владимирович Смирнов - кандидат экономических наук, научный сотрудник, Институт социально-экономических и энергетических проблем Севера Коми научного центра Уральского отделения Российской академии наук. Адрес: 167982, Сыктывкар, ул. Коммунистическая, д. 26. E-mail: av.smirnov.ru@gmail.com
\end{abstract}

Цитирование: Лыткина Т.С., Смирнов А.В. (2019) Российский Север в условиях глобальной неолиберальной политики: преодоление пространственного неравенства или вытеснение? // Мир России. Т. 28. № 3. С. 27-47. DOI: 10.17323/1811-038X-2019-28-3-27-47

Основываясь на данных официальной статистики 2000-2017 г2., в статье приводятся доказательства, что в условиях реализации неолиберальной политики Север оказался в зоне вытеснения, когда из основ сочиильно-экономического порядка исключаются не только люди, но предприятия и территории. В статье эта концепщия развивается применительно к северным регионам России и утверждается, что вытеснение принимает формы институционально организованного исключения через мифологизацию благополучия Севера, ужесточение структур неравенства и экстенсивное использование инфраструктуры, что выражается в снижении уровня и качества жизни северян. Высокие доходы получает лишь незначительная их часть, но и они больше не компенсируют затраты, связанные с работой в суровых климатических условиях и дорогостоящим проживанием на Севере. Показывается, как выстроенная в советские годы инфраструктура также утрачивает свои преимущества, а качество предоставляемьх услуг здравоохранения и образования падает. Иными словами, рыночный механизм разрушает прежние сочиальные гарантии и не способствует формированию долгосрочной стратегии развития Севера, которая со-

1 Статья подготовлена в рамках НИР «Население северных территорий России: история формирования и перспективы развития» (№ ГР АААА-А19-119012190103-0, 2019-2021 гг.). Авторы выражают благодарность за замечания и комментарии, за дружескую поддержку и участие В.В. Фаузеру и С.С. Ярошенко. 
гласовалась бы с современными условиями жизни северян, тем экономическим вкладом, который вносит территория в формирование ВНП и федерального бюджета. При этом дальнейшее игнорирование интересов северян приводит к ухудиению ситуации, к увеличению числа сочиильно уязвимых групп и сохранению ресурсной зависимости. Подчеркивается, что результатом снижения пространственного неравенства в России стало не наращзивание конкурентных преимуществ «слабых» регионов, а обеднение регионов с высоким экономическим потенциалом.

Ключевые слова: неравенство, вытеснение, исключение, бедность, Север, постсоветская Россия, постсоциализм

Во всем мире растет беспокойство, вызванное умножением неравенства, влияющего на экономику стран, политику и общественные процессы. Согласно Дж. Стиглицу, слепая вера в эффективность свободных рынков приводит к увеличению власти монополий и злоупотреблениям в финансовом секторе. Экономическое неравенство порождает неравенство политическое, которое в свою очередь раздувает экономическое неравенство. Вместо того, чтобы выражать интересы широких слоев населения, правительства стран представляют интересы лишь определенных социальных групп [Стиглии 2016, с. 159]. В свою очередь среди граждан растет число тех, кто в результате социального исключения и вовсе лишен возможности заниматься значимой деятельностью и управлять личной жизненной ситуацией [Сен 2004; Сен 2016].

В отличие от экономистов, социологи не только фиксируют рост неравенства в обществе, но и стремятся доказать, что в существовании неравенства заинтересованы представители привилегированных и влиятельных слоев, для которых поляризация и бедность являются необходимыми условиями для реализации своих интересов [Wright 1994, с. 37-50]. Они более всего ратуют за свободную рыночную экономику, но при этом, получая преференции со стороны государства, чаще всего уходят от налогов и не несут социальной ответственности перед обществом. Еще меньшую ответственность они несут на скупаемых территориях в других странах, о которых упоминает С. Сассен, удивляясь жестокости современного мира, когда из основ социально-экономического порядка оказываются вытеснены люди, предприятия и территории. Вытесняемыми одновременно становятся работники с низким уровнем доходов и безработные, не признаваемые программами социального обеспечения, и «пострадавшие от гидравлического разрыва пласта и трансформации природной среды в мертвую зону» [Sassen 2014, p. 2]. Таким образом, социальное неравенство формируется в двух разных направлениях: через создание благоприятных условий и защиты интересов одних - «успешных» (или привилегированных) - и ограничение возможностей для других - «неуспешных» (непривилегированных). Первые становятся обладателями совершенных навыков, востребованных глобальным миром, вторые характеризуются недостатком личных усилий в сфере жизнеобеспечения.

На наш взгляд, понятие «исключения» обладает эвристическими возможностями для выявления действующих механизмов доминирования и извлечения прибыли. Принципиальным моментом данного подхода становится критическое осмысление набора значимых действий и достигаемой с их помощью свободы. В отличие от категории эксплуатации, которая предполагает присвоение прибыли 
определенными социальными классами, контролирующими процесс производства, исключение наиболее уместно к тем формам эксплуатации, которые только еще возникают или остаются невидимыми [Лыткина, Ярошенко 2019]. Но и концепция вытеснения также направлена на изучение новых логик изгнания, которые проявляются как в простейших политических решениях, так и в самых передовых экономических и технических достижениях.

Ключевым моментом данной концепции представляется осознание единства общества и территории, а также критическое осмысление происходящих в современном мире процессов. С одной стороны, мы разделяем эти две концепции, отводя особую роль «социальному исключению» в изучении практик взаимодействия различных социальных групп, способов преодоления или, напротив, (вос)производства бедности внутри общества [Ярошенко 2005; Лыткина 2011]. С другой, мы видим в рассуждениях С. Сассен логичное, с точки зрения полиэкономии, развитие идей А. Сена. Освещаемые Сассен экономические, политические и культурные аспекты становления глобального сообщества сами по себе являются производными уже сформированного режима социального исключения, но в то же время и сильнее закручивающего механизмы доминирования и подавления, распространяя его на все глобальное сообщество. Иными словами, исключение С. Сассен не сконцентрировано на отдельных людях, социальных группах, оно шире и затрагивает сообщества локальных территорий и население стран. Если исключение скрыто в практиках социального взаимодействия и формирует институциональное пространство, то вытеснение главным образом представляет собой уже институционально организованное исключение. Концепция социального исключения предполагает осторожную (чтобы это не привело к неудачному включению) интеграцию индивидов в общество, в то время как вытеснение требует решительного вмешательства политических и общественных сил в решение социальных проблем территорий, регионов, государств.

В своей работе мы применяем теорию вытеснения для характеристики и оценки результатов защиты интересов политических и профессиональных элит, заинтересованных в нормализации структур неравенства, сложившихся в российском обществе в условиях глобализации рыночных отношений. Неравенство регионов выступает в качестве стратегии стабилизации развития и накопления капитала. Наметившееся сближение регионов по показателям доходов не является результатом наращивания конкурентных преимуществ «слабых» регионов, а становится следствием обеднения регионов с высоким экономическим потенциалом. На наш взгляд, теория конкурентных преимуществ, представляющаяся в экономической науке ведущей в объяснении природы регионального неравенства, в случае России служит оправданием наращивания ресурсов в крупных городах и стигматизацией отдельных территорий, постепенно утрачивающих ресурсы для устойчивого социальноэкономического развития, и причиной этому служит политика центра по концентрации бюджетных доходов на федеральном уровне. В отличие от мировой практики, подразумевающей финансовую самостоятельность регионов-доноров, в России стратегии развития территорий определяются федеральным правительством. Являясь финансово-аккумулирующим центром, в котором сконцентрированы политические и профессиональные элиты, защищающие свои интересы, они имеют возможность перенаправлять доходы, получаемые от природных ресурсов, и наращивать собственные ресурсы в программах, не стимулирующих развитие регионов. 
С нашей точки зрения, Север, несмотря на его исключительную важность для экономики страны, становится территорией вытеснения, в границах которого протекают масштабные трансформации различных видов неравенства. Связаны они, прежде всего, с изменением социально-экономической политики государства по отношению к Северу, определившей потребительский способ освоения природных и трудовых ресурсов территории. Мы осознаем, что появившийся новый тип общества в России сложно описать статистическими данными, что проявления неравенств выражаются не только в обобщающих показателях экономической деятельности регионов (ВРП), различиях доходов и материального уровня жизни населения разных территориальных единиц. Не менее показательными становятся характеристики качества жизни населения, включающие в себя широкий спектр показателей, таких как образовательный уровень населения, развитость инфраструктуры, жилищные условия, экологическая обстановка, уровень преступности, а также реализация права человека лично управлять своей жизненной ситуацией.

Мы не претендуем на столь широкий охват изучения проблем различных видов неравенства. В статье основное внимание уделено анализу динамики зарплат, номинальных и реальных доходов населения Севера России в разрезе отраслей, географического расположения регионов, пространственного размещения производительных сил, города, села, возраста и гендера. Также предпринята попытка отразить неравенство доступа к благам с помощью показателей доли благоустроенного ветхого жилья, возможностей детского отдыха, получения качественных медицинских и образовательных услуг. В анализе использованы данные официальной статистики за 2000-2017 гг, полученные из Единой межведомственной информационно-статистической системы ${ }^{2}$ и интернет-портала Федеральной службы государственной статистики ${ }^{3}$, включая статистические сборники, итоги выборочных наблюдений и базу данных показателей муниципальных образований. Однако, прежде всего, мы очертим границы объекта нашего исследования, поместив его в институциональный контекст, поскольку истоки проблем нынешнего российского Севера лежат как в его недавнем советском прошлом, так и в реалиях современного глобального капитализма.

\section{Север России: от богатства к бедности}

В фокусе нашего внимания 13 субъектов РФ, территории которых полностью включены в перечень районов Крайнего Севера и приравненных к ним местностей. Из них пять субъектов РФ расположены в европейской части (Мурманская и Архангельская области, республики Карелия и Коми, Ненецкий автономный округ), а восемь - в азиатской (Ханты-Мансийский и Ямало-Ненецкий автономные округа, республики Тыва и Саха (Якутия), Магаданская и Сахалинская области, Чукотский автономный округ, Камчатский край). По разнообразию и объемам природных ресурсов Север России занимает особое положение. Здесь сосредото-

\footnotetext{
2 https://www.fedstat.ru

3 http://www.gks.ru
} 
чено свыше 80\% всех запасов полезных ископаемых России, в том числе 93\% газа, 90\% алмазов и платиноидов, 83\% серебра, 72\% нефти и газового конденсата, $63 \%$ золота, 43\% угля и множество других видов сырья [Фаузер 2015, с. 131]. Экономическая деятельность ведется примерно на $1 / 4$ части территории российского Севера, причем наиболее освоена его европейская часть.

Динамика исторического развития свидетельствует о существенном влиянии государственного регулирования на промышленное освоение северных территорий и городов России. По мнению историков, Север был призван решать не только экономические, но и политические, и идеологические задачи ${ }^{4}$ [Кириллов 1999, с. 59], что способствовало развернутому широкомасштабному промышленному освоению Севера в советские годы. Реализация государственных задач осуществлялась через принудительное переселение одних социальных групп (политзаключенных и спецпереселенцев), игнорирование интересов других (коренных жителей) и создание преимуществ для третьих (покорителей Севера).

В период сталинских репрессий (1930-1950-е гг.) принудительный труд политзаключенных и спецпереселенцев позволил создать производственные площадки для добычи полезных ископаемых. С середины 1950-1960-х гг. шло активное формирование системы стимулов и поощрений покорителей Севера, для которых было начато строительство развернутой инфраструктурной сети, призванной обеспечить комфортные условия проживания во вновь образованных городах. Центром распределения материальных и социальных благ стало рабочее место [Burawoy 1996]: в привилегированном положении оказались работники нефтегазовой отрасли и угледобычи, которые (по сравнению с другими работниками) имели более высокий социальный статус, лучшее жилье, доступ к дефицитным товарам, возможности респектабельного отдыха и значительные доходы. Но, накопив достаточно денег, они заканчивали долгосрочную вахту, приобретая жилье за пределами Севера и покидая его навсегда [Льткина (1) 2014; Лылткина (2) 2014].

В наиболее сложной ситуации оказались жители сел и деревень, где проживало преимущественно коренное население [Льткина, Фаузер 2016, с. 105], которому вменялся принцип самостоятельного обеспечения семьи [Игнатова 2009, с. 152; Милохин, Сметанин 2005, с. 90; Якоб 2012, с. 31]. Уровень и качество жизни сельских жителей всегда оставались низкими, товаров выделялось мало, а их дома по большей части были неблагоустроенными. Введенный в 1932 г. паспортный режим ограничивал возможности самостоятельного передвижения крестьян даже по территориям, куда принудительно свозились репрессированные. После отмены ограничений в 1974 г. ${ }^{5}$ между городом и деревней установился непрерывный поток людей и ресурсов, однако коренные жители оказались «отрезаны» от рабочих мест в престижных отраслях, и им так и не удалось преодолеть существующие барьеры для интеграции в распределительную систему советского времени.

\footnotetext{
4 Развитие северных территорий позволило решить многие задачи: получить необходимые валютные средства для восстановления экономики после Гражданской войны; обеспечить надежные источники сырья, расположенные как можно дальше от западных границ страны, но близко к его промышленному центру, из-за опасения внешнего вмешательства и угрозы реставрации прежнего строя; реализовать политику трудового воспитания; показать масштабы советской индустриализации и т.д. [Кириллов 1999].

5 Однако полная паспортизация началась 01.01.1976 г. и закончилась 31.12.1981 г.
} 
Процессы исключения продолжаются и сегодня, на этот раз они охватывают гораздо более широкие слои населения Севера. В период перестройки и экономических реформ начала 1990-хх гг. административно-командная система управления подверглась резкой критике, и Север с его огромными богатствами природных ресурсов был признан нерентабельным. Промышленность Севера России утонула в глубоком социально-экономическом кризисе: более половины предприятий были признаны банкротами [Лыткина 2005], а их ничтожные остатки лишь усилили экспортно-сырьевую ориентацию экономики и показали, насколько чревато падение мировых цен на природные ресурсы [Кротов 1998].

Следует отметить, что за относительно короткий исторический период российского капитализма политика по отношению к Северу сменилась, что нашло свое отражение в преобразовании системы распределения благ, налоговой политики в сфере добычи природных ресурсов ${ }^{6}$ и в критериях получения дотаций из федерального бюджета. В настоящее время приоритеты федеральных властей при инвестировании регионов носят в основном политический характер, тогда как интересы крупного бизнеса сконцентрированы в проектах по добыче и транспортировке нефти ${ }^{7}$ [Зубаревич 2010]. Если политические приоритеты применительно к Северу способствовали его выпадению из системы распределения бюджетных средств Российской Федерации, то развитие на этих территориях крупного бизнеса усилило его ресурсную специализацию. Экономическое развитие осложняет тот факт, что 90\% промышленных предприятий Севера зарегистрированы за его пределами [Стыров 2012] и их руководство не заинтересовано в развитии территорий, где ведут производственную деятельность. В последнее время мелкий и средний бизнес вытесняется международными компаниями и крупными корпорациями других регионов России. В результате, несмотря на высокий экономический потенциал северных регионов, перспективы их социально-экономического развития в долгосрочной перспективе представляются весьма сомнительными.

Между тем для большинства граждан страны Север продолжает ассоциироваться с огромными запасами природных ресурсов и высоким уровнем жизни северян, однако сами жители Севера все чаще испытывают незнакомые ранее ощущения периферийности, отрезанности от внешнего мира, социального исключения и ненужности [Лыткина (2) 2014, с. 147]. При этом мы не наблюдаем возмущений и социальных протестов, поскольку, с одной стороны, единственные сообщества людей, обладавшие при прежнем политическом режиме потенциалом солидарного действия (трудовые коллективы), утратили способность к мобилизации, а с другой, законодательная база РФ препятствует публичному проявлению коллективного

\footnotetext{
6 В 2003 г. снижена региональная доля налога на добычу полезных ископаемых (НДПИ) на газ с 20 до $0 \%$, на нефть - с 20 до 14\%; в 2004 г. вновь сокращена региональная доля НДПИ на нефть до 5\%, а с 2009 г. НДПИ на природный газ и нефть стал полностью зачисляться в федеральный бюджет. В 2017 г. федеральный центр сократил норматив зачисления налога на прибыль в региональные бюджеты с 18 до 17\%, а также уменьшил долю акцизов на нефтепродукты, зачисляемые в бюджеты регионов до $61,7 \%$. Наконец, в 2018 г. регионы потеряли часть бюджетных доходов из-за индексации НДПИ, который уменьшил базу налога на прибыль [Юиков, Одинг, Савулькин 2017, с. 68].

7 Для примера: доля инвестиций в основной капитал в валовом региональном продукте (ВРП) Республики Коми выросла в 2005-2015 гг. с 29,4 до 33,5\%, при этом более 82\% инвестиций приходятся на добычу нефти и газа, а также на трубопроводный транспорт. Если исключить эти виды экономической деятельности, то окажется, что другие инвестиции сократились с 9 до $6 \%$ от ВРП.
} 
недовольства. Однако основная проблема с демонстрацией гражданского активизма заключается в том, что в предыдущие исторические периоды интересы и требования различных социальных групп регулярно подавлялись и/или игнорировались, что нашло отражение в практиках взаимодействия различных социальных групп и снобизме одних граждан при молчаливом сопротивлении других.

Несмотря на то, что северные регионы России обеспечивают 38,4\% поступлений в федеральный бюджет, они не имеют финансовой самостоятельности, возможностей для диверсификации экономики и защиты от последствий ее ресурсной ориентированности. Север не обладает переговорной силой с федеральными властями, а население, не имеющее коллективной идентичности, оказалось неспособно сформулировать общие интересы и защитить свои права. Иначе обстоит дело с регионами, обладающими геополитическими преимуществами и способными манипулировать национальными интересами: даже если ответом на региональный шантаж становится политика «короткого поводка», предполагающая получение дотаций от государства, а не формирование долгосрочных стратегий развития регионов, эти территории, тем не менее, имеют больше возможностей для реабилитации экономик и повышения качества жизни населения, чем Север ${ }^{8}$.

Демонстрируя скромные экономические и социальные показатели, многие регионы продолжают развиваться в рамках неформальных экономик. Их удельный вес возрастает по мере движения с севера на юг и с запада на восток [Барсукова 2004, с. 100]. В 2015 г. на Севере доля неформальной занятости составила 15\%, в Северо-Кавказском, Крымском и Южном федеральных округах $45,6,38,3$ и 27,6\% от общей численности занятого населения соответственно ${ }^{\text {, пре- }}$ дельных значений она достигает в Дагестане $(56,5 \%)$ и Чечне $(63,0 \%)$. Речь идет не о сдаче в аренду жилья или о продаже овощей и фруктов, выращенных на приусадебном участке, а об организованном бизнесе: сети заправочных, мебельных салонов, придорожных мотелей и комфортабельных гостиниц для отдыхающих. Это значительная часть экономики, которая не попадает в статистическую и налоговую отчетность, но определяет качество жизни населения. Если придерживаться точки зрения П. Галаши и Е. Шика о том, что неформальная экономика является стабилизирующим фактором в периоды экономического спада, одновременно приводящей к увеличению неравенства через сокращение доходов государства и экономии на социальной сфере [Galasi, Sík 1988, pp. 165-165], то можно утверждать, что государству выгодно игнорировать масштабы неформальной экономики и не контролировать сбор налоговых отчислений от предпринимательской деятельности. Помимо этого, выделяя ежегодные дотации, оно еще меньше заинтересовано в выработке долгосрочных стратегий развития этих регионов. Учитывая, в пользу каких регионов идет перераспределение государственного бюджета и благодаря каким он формируется, можно признать как факт уязвимость Севера, его вытеснение и как следствие падение качества жизни северян.

\footnotetext{
8 Косвенным доказательством служат показатели ВРП на душу населения, которые сокращаются в северных регионах и растут в южных [Преодоление пространственного неравенства 2018, с. 31]. Кроме того, не требует доказательства и истощение природных ресурсов.

9 Рабочая сила, занятость и безработица в России (2016) // Федеральная служба государственной статистики // http://www.gks.ru/bgd/regl/b16_61/Main.htm
} 


\section{Благополучие российского Севера: миф или реальность?}

Ученые, занимающиеся вопросами регулирования бедности, доказали, что устанавливаемый в России минимальный доход больше не является предпосылкой для полноценного участия в жизни общества и гарантией объективной свободы [Chetvernina 1995, p. 50-51; Овчарова 2001; Овчарова, Попова 2013]. Также отмечается, что только за первое десятилетие капитализма в России коэффициент Джини вырос с 0,260 в 1991 г. до 0,397 в 2001 г., определив резкую дифференциацию населения. В последующее десятилетие доходы наиболее обеспеченных групп населения продолжали расти, в то время как для бедных людей была характерна консервация доходов даже тогда, когда официальная статистика начала фиксировать сокращение неравенства (2012-2017 гг.) ${ }^{10}$.

Ситуация на Севере сложилась еще острее. Если в России в целом в 2006 г. реальные располагаемые доходы населения превысили уровень 1991 г., то на Севере, несмотря на их рост в 2000-х гг., они так и не вернулись к прежнему уровню ${ }^{11}$. Пик доходов в северных территориях пришелся на 2007 г. (97,6\%), затем они начали сокращаться, достигнув в 2017 г. значения 66,5\% от уровня 1991 г., при этом за тот же период в среднем по стране реальные располагаемые доходы выросли до $122,2 \%$. Что касается прожиточного минимума на Севере, то с начала $2000-\mathrm{x}$ гг. до конца 2016 г. его размер увеличился в 8 раз ${ }^{12}$ и составил 13035 руб. (в России - 9691 руб.). Доля бедных с доходами ниже прожиточного минимума в общей численности населения снизилась с $26,6 \%$ в 2000 г. до $15,4 \%$ в 2017 г. (за тот же период в среднем по стране бедность сократилась с 29,0\% до 13,2\%) ${ }^{13}$. Иными словами, процессы (вос)производства бедности на Севере протекают интенсивнее и бедных становиться больше, несмотря на более высокие доходы по сравнению с остальными россиянами.

Согласно статистике, среднемесячная заработная плата по России в 2016 г. составила 36709 руб., а на Севере на 53\% выше (56104 руб.), однако еще в начале 2000-х гг. средняя зарплата на Севере превосходила среднероссийскую более чем вдвое. К 2010 г. разница сократилась до полутора раз, что свидетельствует о замедлении роста заработных плат работников Севера. Так, например, если в отрасли по добыче полезных ископаемых в среднем по России с 2002 по 2016 г. произошло увеличение заработной платы в 6,3 раза в текущих ценах, то на Севере только

\footnotetext{
10 Коэффициент Джини достиг максимума в 2012 г. (0,420), после чего сократился до 0,410 (Коэффициент Джини // ЕМИСС // https://www.fedstat.ru/indicator/31165).

11 Динамика распределения доходов населения северных регионов проиллюстрирована на примере Республики Коми, занимающей в структуре экономики промежуточную позицию между добывающими, перерабатывающими и социальными регионами Севера. На северо-востоке Республики Коми расположены территории, где развита добыча полезных ископаемых и фиксируются высокие доходы населения, в других же частях республики преобладают лесное и сельское хозяйство, а также социальный сектор.

12 Средняя взвешенная стоимость минимального набора продуктов питания на Севере на конец 2017 г. составила 4939 руб. При несложных математических вычислениях в день на человека приходится около 165 руб.: завтрак, обед и ужин должны обходиться примерно в 55 руб. В перерасчете на доллары США (средний курс одного доллара в 2017 г. составил 58 руб. 30 коп.) выходит 2 доллара 82 цента в день. Доля расходов на продукты питания в северных регионах составляет $32,4 \%$ от бюджета домохозяйств.

13 Рассчитано авторами по данным ЕМИСС (Доля населения с денежными доходами ниже величины прожиточного минимума, установленной в субъекте Российской Федерации // ЕМИСС // https://www.fedstat.ru/indicator/43713).
} 
в 4,9 раза ${ }^{14}$. Такая тенденция наблюдается по всем отраслям Севера, и нет ни одной отрасли, в которой заработная плата на Севере росла бы быстрее, чем в России.

Федеральный закон № 122 от 22.08.2004 г. предполагает компенсацию за проживание в сложных климатических условиях и гарантирует северные надбавки ${ }^{15}$ только работникам бюджетной сферы, что не исключает данного права для работников других отраслей экономики, в том числе частной формы собственности. Учитывая, что повышающий коэффициент работы на Севере зависит не только от географического положения региона, но и от стажа работы на Севере, средняя заработная плата в северных регионах должна разниться от полутора до трех среднероссийских зарплат (в среднем на 207\%). Близкой к данным значениям она была еще в 2002 г. и превышала зарплату по стране на 216\%. К 2016 г., как мы отмечали выше, она существенно сократилась и составила уже 153\%. В наиболее высокооплачиваемой отрасли (добыча полезных ископаемых) заработная плата в 2002 г. составляла $455 \%$ от среднероссийской; в 2016 г. $-264 \%{ }^{16}$.

Сравнение России и Севера внутри отраслей показало, что существенная разница в оплате труда на 2016 г. наблюдается в переработке, энергетике, строительстве, транспорте и связи - 52\%. В наиболее высокооплачиваемой отрасли (добычи полезных ископаемых) разница составляет $38 \%$, такая же - в сфере социального воспроизводства, в сельском хозяйстве - $34 \%$, в финансах, недвижимости и государственном управлении - 25\%. В 2002 г. разница составляла 102, 79, 91 и 59\% соответственно. Наконец, следует отметить, что заработная плата в сфере торговли, гостиничного и ресторанного бизнеса на Севере сегодня даже ниже, чем в целом по России, в то время как в 2002 г. разница составляла 94\%. (таблица 1). Все представленные расчеты показывают, что северные надбавки все меньше учитывают сложности работы и влияние удорожающих факторов на Севере.

Высокие заработки характерны преимущественно для занятых на предприятиях, добывающих полезные ископаемые: по данным Росстата, заработная плата в 2016 г. в этой отрасли составила 96862 руб., при этом следует учитывать, что в ней занято всего 10,4\% работников северных регионов. В низкооплачиваемой сфере социального воспроизводства (образование, здравоохранение и социальные услуги) зарплата намного меньше (40715 руб., что на 27,5\% ниже средней по Северу и практически соответствует среднероссийскому уровню, здесь занято $20,4 \%$ работников). В наиболее «бедных» отраслях (сельское хозяйство, охота и лесное хозяйство, сфера услуг) заработная плата вдвое ниже средних по северным регионам и меньше средних по России и составляет 28848 руб. (в этих отраслях заняты $18,9 \%$ работников) $)^{17}$. Таким образом, зарплаты около $40 \%$ работников Севера находятся на уровне среднероссийских или даже ниже. Если учесть, что руководство предприятий добывающей отрасли не заинтересовано в приеме на работу местных жителей и активно ис-

\footnotetext{
14 Рассчитано авторами по данным сборников Росстата «Рынок труда, занятость и заработная плата».

15 Федеральный закон от 22.08.2004 N 122-Ф3 «О внесении изменений в законодательные акты Российской Федерации и признании утратившими силу некоторых законодательных актов Российской Федерации в связи с принятием федеральных законов “О внесении изменений и дополнений в Федеральный закон “Об общих принципах организации законодательных (представительных) и исполнительных органов государственной власти субъектов Российской Федерации” и “Об общих принципах организации местного самоуправления в Российской Федерации"».

16 Рассчитано авторами по данным сборников Росстата «Рынок труда, занятость и заработная плата».

17 Рассчитано авторами по данным сборников Росстата «Рынок труда, занятость и заработная плата».
} 
пользует вахтовый метод организации труда с привлечением внешних работников ${ }^{18}$, а заработная плата фиксируется органами статистики в регионах, где ведется производственная деятельность (в отличие от прибыли, которая достается регионам, где предприятия зарегистрированы), то богатых северян еще меньше, чем демонстрирует представленный анализ, не учитывающий число пенсионеров и безработных.

Таблица 1. Отношение среднемесячной заработной платы работников по видам экономической деятельности Севера к средней по России, 2002-2016 гг., \%

\begin{tabular}{|l|l|c|c|c|c|c|c|}
\hline & Вид экономической деятельности & $\mathbf{2 0 0 2}$ & $\mathbf{2 0 0 5}$ & $\mathbf{2 0 1 0}$ & $\mathbf{2 0 1 4}$ & $\mathbf{2 0 1 5}$ & $\mathbf{2 0 1 6}$ \\
\hline \multirow{5}{*}{ Россия } & Всего & $\mathbf{1 0 0}$ & $\mathbf{1 0 0}$ & $\mathbf{1 0 0}$ & $\mathbf{1 0 0}$ & $\mathbf{1 0 0}$ & $\mathbf{1 0 0}$ \\
\cline { 2 - 8 } & Добыча полезных ископаемых & 254 & 231 & 190 & 181 & 187 & 191 \\
\cline { 2 - 8 } & Финансы, недвижимость, гос. управление & 134 & 139 & 134 & 132 & 129 & 130 \\
\cline { 2 - 8 } & Строительство, транспорт и связь & 125 & 122 & 114 & 104 & 104 & 103 \\
\cline { 2 - 8 } & Переработка, энергетика & 108 & 104 & 96 & 94 & 97 & 97 \\
\cline { 2 - 8 } & Социальная сфера & 70 & 67 & 72 & 82 & 82 & 80 \\
\cline { 2 - 8 } & Торговля, гостиницы и рестораны & 70 & 76 & 85 & 77 & 77 & 79 \\
\cline { 2 - 8 } & Сельское и лесное хозяйство & 43 & 43 & 51 & 55 & 58 & 59 \\
\hline \multirow{4}{*}{\begin{tabular}{l} 
Ревер \\
\cline { 2 - 8 }
\end{tabular}} & Всего & $\mathbf{2 1 6}$ & $\mathbf{1 8 9}$ & $\mathbf{1 5 9}$ & $\mathbf{1 5 4}$ & $\mathbf{1 5 5}$ & $\mathbf{1 5 3}$ \\
\cline { 2 - 8 } & Добыча полезных ископаемых & 455 & 380 & 286 & 259 & 265 & 264 \\
\cline { 2 - 8 } & Финансы, недвижимость, гос. управление & 213 & 203 & 180 & 173 & 168 & 162 \\
\cline { 2 - 8 } & Строительство, транспорт и связь & 252 & 215 & 171 & 155 & 156 & 157 \\
\cline { 2 - 8 } & Переработка, энергетика & 189 & 171 & 148 & 140 & 146 & 147 \\
\cline { 2 - 8 } & Социальная сфера & 130 & 110 & 100 & 116 & 115 & 111 \\
\cline { 2 - 8 } & Торговля, гостиницы и рестораны & 136 & 116 & 90 & 79 & 79 & 78 \\
\cline { 2 - 7 } & Сельское и лесное хозяйство & 82 & 75 & 73 & 72 & 77 & 79 \\
\hline
\end{tabular}

Составлено на основе данных сборников Росстата «Рынок труда, занятость и заработная плата» (сведения от организаций на выборочной основе). По Северу России приведены средние взвешенные по числу занятых значения показателей 13 северных регионов.

Итак, на основании расчета динамики реальных доходов и соотношения заработной платы в России и российском Севере можно заключить, что за последние два десятилетия благополучие северян снизилось. Рыночный механизм разрушил заложенные в советское время компенсации за труд и проживание в сложных климатических условиях, а извлечение прибыли за счет ресурсов прошлого (в том числе природных ресурсов) ради интересов проживающих на Севере граждан не контролируется.

\footnotetext{
18 Мы располагаем лишь обрывочными данными о численности работающих вахтовым методом: во II квартале 2014 г. в Тюменской области насчитывалось 189 тыс. чел.; в I квартале 2018 г. - 19 тыс. чел. в Республике Коми и 39 тыс. чел. в Якутии; в IV квартале 2017 г. из 88 тыс. вахтовых работников Ямало-Ненецкого АО лишь 19\% были постоянными жителями округа (Основные показатели рынка труда. Ямало-Ненецкий АО: статистический сборник-2017(2018)//http://rabota.yanao.ru/cms_data/usercontent/regionaleditor/издания/основные\%20показатели\%20 рынка\%20труда\%20янао\%20за\%202017\%20год.pdf).
} 


\section{Механизмы вытеснения или структуры неравенства?}

Неравенство пронизывает все структуры общества: микроданные выборочного наблюдения доходов населения и участия в социальных программах Росстата 2017 г. ${ }^{19}$ демонстрируют, что имеется огромная разница в уровне заработных плат между разными социальными группами (таблица 2). Мы выделили пять видов неравенств: отраслевое, пространственное, урбанизационное, возрастное и гендерное.

Таблица 2. Отношение заработной платы северных регионов к средней по Северу России по типу населенного пункта, классам и виду экономической деятельности и полу, 2017 г., \%

\begin{tabular}{|c|c|c|c|c|c|c|c|c|c|c|c|}
\hline \multirow{3}{*}{$\begin{array}{l}\text { Тй } \\
\text { насе- } \\
\text { ленного } \\
\text { пункта }\end{array}$} & \multirow{3}{*}{$\begin{array}{l}\text { Вид эконо- } \\
\text { мической } \\
\text { деятель- } \\
\text { ности }\end{array}$} & \multicolumn{10}{|c|}{ Экономические классы и пол } \\
\hline & & \multicolumn{2}{|c|}{$\begin{array}{c}\text { руководи- } \\
\text { тели }\end{array}$} & \multicolumn{2}{|c|}{ специалисты } & \multicolumn{2}{|c|}{ служащие } & \multicolumn{2}{|c|}{$\begin{array}{c}\text { квалифици- } \\
\text { рованные } \\
\text { рабочие }\end{array}$} & \multicolumn{2}{|c|}{$\begin{array}{c}\text { неквалифи- } \\
\text { цированные } \\
\text { рабочие }\end{array}$} \\
\hline & & муж. & жен. & муж. & жен. & муж. & жен. & муж. & жен. & муж. & жен. \\
\hline \multirow{3}{*}{ городской } & $\begin{array}{l}\text { промышлен- } \\
\text { ность }\end{array}$ & 199 & 181 & 156 & 122 & 118 & 70 & 116 & 71 & 95 & 54 \\
\hline & $\begin{array}{l}\text { социаль- } \\
\text { ная сфера }\end{array}$ & 135 & 109 & 102 & 82 & 61 & 56 & 76 & 54 & 43 & 41 \\
\hline & $\begin{array}{l}\text { другие } \\
\text { отрасли }\end{array}$ & 175 & 129 & 147 & 95 & 94 & 62 & 89 & 65 & 67 & 43 \\
\hline \multirow{3}{*}{ сельский } & $\begin{array}{l}\text { промышлен- } \\
\text { ность }\end{array}$ & 166 & 156 & 127 & 105 & 119 & 70 & 93 & 64 & 61 & 57 \\
\hline & $\begin{array}{l}\text { социаль- } \\
\text { ная сфера }\end{array}$ & 107 & 106 & 84 & 75 & 36 & 43 & 43 & 31 & 35 & 34 \\
\hline & $\begin{array}{l}\text { другие } \\
\text { отрасли }\end{array}$ & 142 & 92 & 142 & 88 & 79 & 53 & 74 & 58 & 42 & 34 \\
\hline
\end{tabular}

Составлено на основе микроданных выборочного наблюдения доходов населения и участия в социальных программах Росстата за 2017 г.

Сложность анализа выделенных видов неравенства на Севере России заключается в том, что все они усиливают и обуславливают друг друга. Тем не менее наиболее значимым видом неравенства является отраслевое ввиду особой роли добычи природных ресурсов в экономике Севера. Коэффициент корреляции Пирсона, свидетельствующий о линейной связи между вкладом добычи полезных ископаемых в ВРП и социальным неравенством (коэффициент Джини) на российском Севере, равен 0,872. Отраслевое неравенство мы рассмотрели выше и будем к нему возвращаться в ходе представления последующего материала. Добавим, что внутри отраслей велика дифференциация по экономическому статусу: например,

\footnotetext{
19 Выборочное наблюдение доходов населения и участия в социальных программах (2017) // Федеральная служба государственной статистики // http:/gks.ru/free_doc/new_site/vndn-2017/index.html; выборка наблюдения на Севере составила 28577 чел.
} 
в сравнении с неквалифицированными рабочими у руководителей зарплаты выше в 2,9 раз, у специалистов - в 2,1 раза, у квалифицированных рабочих - в 1,8 раза, у служащих - в 1,3 раза $^{20}$.

Размещение производительных сил по северным территориям определяет пространственное неравенство. Самые низкие заработные платы - в Республике Тыва (29828 руб.), в экономике которой преобладают социальная сфера (25,6\% добавленной стоимости) и государственное управление $(22,4 \%)$; другие отрасли экономики развиты слабо, в связи с чем регион можно уверенно назвать социальным. Относительно невысоки заработные платы (33061-48986 руб.) и в перерабатывающих регионах Русского Севера - Мурманской и Архангельской областях, республиках Карелия и Коми, где сохраняется высокий по северным меркам вклад обрабатывающих производств $(11,3-15,6 \%)$. Все четыре региона находятся в европейской части Севера. В Республике Коми и Мурманской области помимо этого развита добыча полезных ископаемых (14,7-36,4\%), что позволяет называть их экономику комплексной. Самые высокие заработные платы (59000-86647 руб.) концентрируются в группе добывающих регионов (Ханты-Мансийский, ЯмалоНенецкий, Ненецкий и Чукотский автономные округа, Республика Саха, Магаданская и Сахалинская области). Удельный вес добычи полезных ископаемых в их добавленной стоимости составляет от 28,9 до $67,8 \%$. Близкое к ним положение по уровню заработных плат занимает Камчатский край (61159 руб.), где низка доля добычи $(4,9 \%)$, но развито рыболовство $(17,0 \%)^{21}$.

Заработные платы в районах Крайнего Севера в среднем на 27\% выше, чем в приравненных к ним местностях, а в азиатской части Севера на $54 \%$ выше, чем в европейской. Примечательно, что для азиатской части характерны как наиболее богатые, так и наиболее бедные местности. В десяти самых «бедных» сельских районах Севера (все они сконцентрированы в Республике Тыва) средний размер заработной платы меньше 20000 руб. Причем доходы практически половины жителей Тывы ниже 10000 руб. В десяти наиболее «богатых» районах средний размер заработной платы превышает 90000 руб. ${ }^{22}$; это добывающие районы и районы с наиболее экстремальными природно-климатическими условиями (городские округа Ногликский, Анадырь, Новый Уренгой, Омсукчанский, Северо-Эвенский и Новая Земля, а также муниципальные районы Надымский, Мирнинский, Карагинский и Анабарский).

Под урбанизационным неравенством мы подразумеваем неравенство, которое стало результатом агломерационного эффекта, дающего преимущества территориям с высокой концентрацией населения, поскольку пространственная близость повышает степень разделения труда и эффективность взаимодействия, обеспечивая рост экономики и доходов населения урбанизированных территорий [Scott 2014]. На Севере России в районах с преобладанием городского населения ${ }^{23}$ заработные

20 Рассчитано авторами по микроданным выборочного наблюдения доходов населения и участия в социальных программах Росстата за 2017 г. (Выборочное наблюдение доходов населения и участия в социальных программах (2017) // Федеральная служба государственной статистики // http://www.gks.ru/free_doc/new_site/vndn-2017/index.html).

21 Регионы России. Социально-экономические показатели - 2017 г. // Федеральная служба государственной статистики // http://www.gks.ru/bgd/regl/B17_14p/Main.htm

22 База данных показателей муниципальных образований. Росстат // Федеральная служба государственной статистики // http://www.gks.ru/dbscripts/munst/

23 В 14 крупных городах (более 100 тыс. чел.) и 10 средних (от 50 до 100 тыс.) проживает 49\% населения северных регионов. 
платы в среднем на 85\% выше, чем в сельских районах. Здесь вновь важную роль играют различия в отраслевой структуре экономики, а также более высокий удельный вес пожилых людей, проживающих в сельской местности. Также следует отметить, что крупные городские поселения предоставляют своим жителям более широкий спектр товаров и услуг, усиливая тем самым контраст в качестве жизни по сравнению с сельскими жителями.

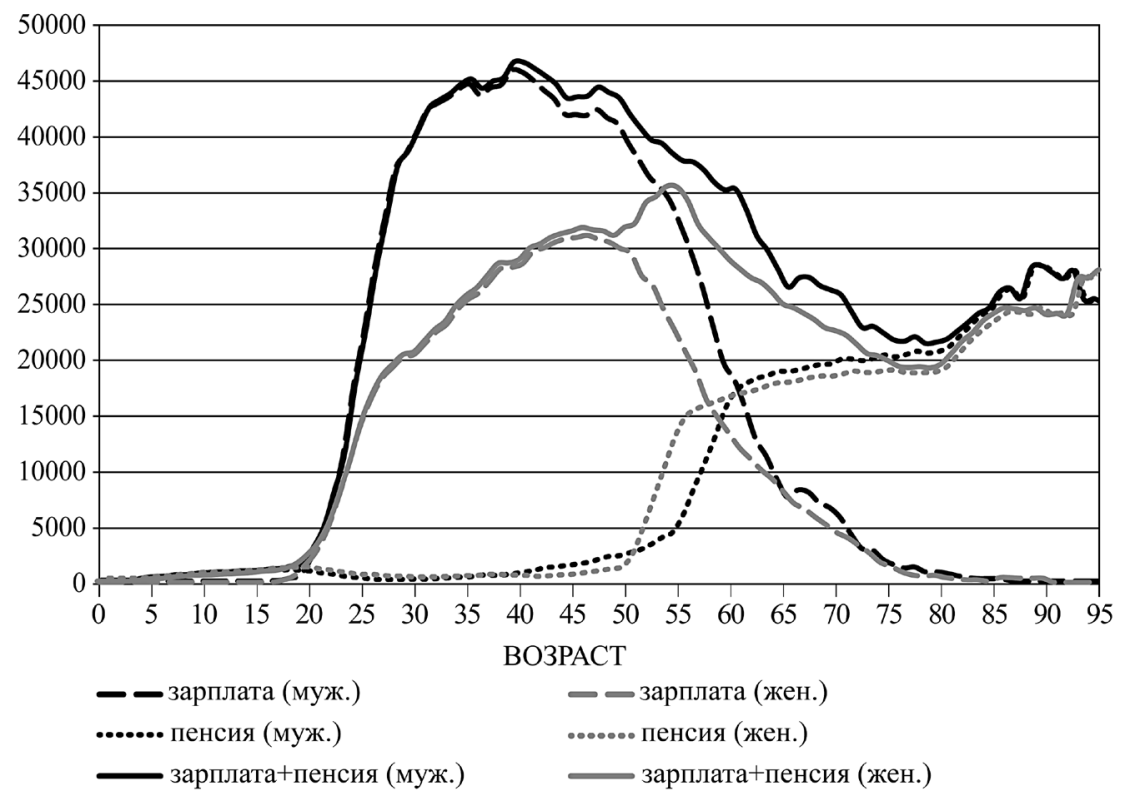

Рисунок 1. Заработная плата (по основному месту работы с учетом социального пакета) и пенсия населения Севера России по полу, 2017 г., руб. ${ }^{24}$

Не менее показательно возрастное и гендерное неравенство, которому научным сообществом уделяется особое внимание [Мезенцева 2001; Хасбулатова 2001; Мальцуева, Рощин 2007; Козина 2009]. Авторы подчеркивают существование «стеклянного потолка», гендерной сегрегации, различий в трудовой мобильности и ощутимой разницы в оплате труда между полами, однако при анализе гендерных проблем слабо учитывается региональная специфика. Не претендуя на всесторонний анализ, отметим, что зарплаты мужчин на Севере в среднем на 47\% выше, чем у женщин (38\% в среднем по России), а размер пенсий - на 3\% (5\% по России). Разница в доходах между полами становится ощутимой практически сразу после начала трудовой карьеры в возрасте 21 года (рисунок 1). Своего максимума она достигает в возрасте 2832 лет, когда наблюдается почти двукратное превосходство доходов мужчин, после чего разница постепенно начинает сокращаться. Пик доходов у мужчин приходится

24 Составлено на основе микроданных выборочного наблюдения доходов населения Росстата. Графики сглажены методом скользящего среднего по пяти ближайшим значениям. 
на 35-50 лет, у женщин - 53-57 лет ${ }^{25}$, когда они еще продолжают работать, но уже получают пенсию, однако даже в этом случае доходы женщин остаются ниже по сравнению с доходами мужчин. В возрасте 75-80 лет у обоих полов наблюдается локальный минимум доходов. Несмотря на то, что после 80 лет средние пенсии увеличиваются, дожить до этого возраста удается немногим, поскольку ожидаемая продолжительность жизни при рождении на Севере составляет немногим более 70 лет.

Выделив пять видов неравенства, мы еще раз показали значимость отраслевого фактора в формировании неравенства на Севере, обуславливающего остальные его виды. Мы продемонстрировали, что высокие доходы отнюдь не характерны для всего Севера, напротив, они размещены точечно и сильно дифференцированы: наиболее высокие доходы сконцентрированы в азиатской части Крайнего Севера, исключительно в добывающих районах и только в местностях с экстремальными природными условиями. Например, в Анабарском национальном улусе (районе) Якутии, где добываются алмазы, средняя заработная плата вдвое выше, чем в соседних районах, в экономике которых преобладают промыслы и социальная сфера, при этом уровень жизни сельских жителей гораздо ниже чем у горожан, а у мужчин выше, чем у женщин. Опираясь на данные статистики, нам удалось зафиксировать лишь структуры неравенств, тогда как для выявления механизмов вытеснения нужны данные о реакциях местного и федерального правительств, граждан, проживающих на Севере, а также других агентов ${ }^{26}$, влияющих на переговоры относительно способов накопления и распределения имеющихся ресурсов.

\section{Инфраструктура Севера: комфортное проживание или выживание?}

В советский период строительство развернутой инфраструктурной сети было призвано обеспечить комфортные условия проживания в суровых климатических условиях. Считалось, что, будучи удаленными от основных экономических центров, северные города должны были иметь у себя весь необходимый спектр базовых услуг [Замятина, Гончаров 2017, с. 169]. Способна ли сегодня выстроенная инфраструктура компенсировать работу в условиях Севера?

Согласно таблиие 3, до 2000 г. Север обладал более благоустроенным жилищным фондом (водопровод, канализация, отопление, ванны, водоснабжение и электроплиты), доставшимся преимущественно с советских времен. Он все еще сохраняет лидерство по водоотведению, ваннам и электроплитам, но преимущество Севера в развитости инфраструктуры стремительно сокращается. Несмотря на то, что газ добывается преимущественно в северных регионах (в первую очередь в Ямало-Ненецком автономном округе), степень газификации жилищного фонда Севера снижается и характеризуется двукратным отставанием по сравне-

\footnotetext{
25 Пенсия в связи с работой на Крайнем Севере устанавливается: мужчинам - по достижении 55 лет и женщинам по достижении 50 лет, если они проработали не менее 15 календарных лет в районах Крайнего Севера либо не менее 20 календарных лет в местностях, приравненных к районам Крайнего Севера, и имеют общий трудовой стаж соответственно не менее 25 и 20 лет (Приказ Минтруда РСФСР от 22.11.1990 N 2 (ред. от 11.07.1991, с изм. от 01.12.2015)).

26 В частности, международного и регионального бизнеса (корпораций) и Всемирного Банка, определявшего политику экономической реструктуризации в России.
} 
нию с Россией ${ }^{27}$. Не лучшим образом выглядит статистика, характеризующая износ жилищного фонда, который на Севере в 3,3 раза выше среднего по стране, при том что по России в целом он снижается.

Таблица 3. Динамика инфраструктуры России и северных регионов, 2000-2016 гг.

\begin{tabular}{|c|c|c|c|c|c|c|c|c|c|c|c|}
\hline \multirow{2}{*}{\multicolumn{2}{|c|}{ Показатель }} & \multicolumn{5}{|c|}{ Россия } & \multicolumn{5}{|c|}{ Север России } \\
\hline & & $2000 *$ & 2005 & 2010 & 2015 & 2016 & $2000 *$ & 2005 & 2010 & 2015 & 2016 \\
\hline \multicolumn{12}{|c|}{ Жилищно-коммунальное хозяйство } \\
\hline \multicolumn{2}{|c|}{$\begin{array}{l}\text { Удельный вес ветхого } \\
\text { и аварийного жилищного фонда, \% }\end{array}$} & 3,1 & 3,2 & 3,1 & 2,5 & 2,4 & 6,5 & 7,3 & 8,0 & 7,5 & 8,0 \\
\hline \multirow{7}{*}{$\begin{array}{l}\text { Удельный } \\
\text { вес общей } \\
\text { площади } \\
\text { жилищного } \\
\text { фонда, } \\
\text { оборудован- } \\
\text { ной: }\end{array}$} & водопроводом & 74,0 & 75,6 & 77,7 & 81,4 & 81,9 & 76,1 & 76,9 & 77,5 & 79,1 & 79,4 \\
\hline & канализацией & 69,7 & 71,5 & 73,7 & 76,8 & 77,1 & 74,2 & 75,5 & 76,0 & 77,3 & 77,6 \\
\hline & отоплением & 74,5 & 79,8 & 83,1 & 85,4 & 85,6 & 77,3 & 81,1 & 81,7 & 83,8 & 84,1 \\
\hline & ванной (душем) & 64,3 & 65,4 & 66,7 & 69,2 & 69,5 & 70,6 & 71,1 & 71,5 & 73,1 & 73,4 \\
\hline & $\begin{array}{l}\text { газом } \\
\text { (сетевым, сжиженным) }\end{array}$ & 70,2 & 70,1 & 69,0 & 66,7 & 66,3 & 34,9 & 34,5 & 34,8 & 33,3 & 33,1 \\
\hline & горячим водоснабжением & 60,8 & 62,9 & 64,9 & 68,1 & 68,7 & 64,3 & 65,7 & 67,2 & 67,6 & 67,8 \\
\hline & $\begin{array}{l}\text { напольными } \\
\text { электроплитами }\end{array}$ & 16,3 & 17,4 & 18,9 & 21,5 & 22,6 & 37,4 & 38,9 & 39,3 & 42,4 & 42,7 \\
\hline \multicolumn{12}{|c|}{ Здравоохранение } \\
\hline $\begin{array}{l}\text { Мощность ам } \\
\text { организаций, }\end{array}$ & $\begin{array}{l}\text { булаторно-поликлинических } \\
\text { посещений на } 10 \text { тыс. чел. }\end{array}$ & 245 & 256 & 258 & 264 & 267 & 254 & 292 & 294 & 304 & 308 \\
\hline $\begin{array}{l}\text { Заболеваемос } \\
\text { (диагноз уста }\end{array}$ & $\begin{array}{l}\text { :ть на } 1000 \text { чел. населения } \\
\text { новлен впервые в жизни) }\end{array}$ & 731 & 744 & 780 & 778 & 785 & 918 & 918 & 974 & 953 & 972 \\
\hline \multicolumn{12}{|c|}{ Культура и отдых } \\
\hline $\begin{array}{l}\text { Численность } \\
\text { на } 1000 \text { чел. }\end{array}$ & $\begin{array}{l}\text { зрителей театров, человек } \\
\text { населения }\end{array}$ & 210 & 195 & 217 & 261 & 265 & 127 & 131 & 147 & 170 & 168 \\
\hline $\begin{array}{l}\text { Число посещ } \\
1000 \text { чел. нас }\end{array}$ & $\begin{array}{l}\text { ений музеев, человек на } \\
\text { еления }\end{array}$ & 499 & 527 & 567 & 813 & 842 & 293 & 387 & 409 & 501 & 523 \\
\hline $\begin{array}{l}\text { Численность } \\
\text { в детских озд } \\
\text { за лето, чело }\end{array}$ & $\begin{array}{l}\text { детей, отдохнувших } \\
\text { оровительных учреждениях } \\
\text { зек на } 1000 \text { чел. населения }\end{array}$ & 42,1 & 39,5 & 34,3 & 31,8 & 32,6 & 34,4 & 34,0 & 27,6 & 28,8 & 30,7 \\
\hline \multicolumn{12}{|c|}{ Образование } \\
\hline $\begin{array}{l}\text { Доля обучаю } \\
\text { смены по прс } \\
\text { общего образ }\end{array}$ & $\begin{array}{l}\text { щихся во вторую и третью } \\
\text { граммам } \\
\text { ования, \% }\end{array}$ & 20,8 & 15,0 & 13,1 & 13,4 & 12,8 & 23,4 & 17,5 & 14,1 & 15,4 & 13,4 \\
\hline $\begin{array}{l}\text { Численность } \\
\text { населения }\end{array}$ & студентов на 10000 чел. & 324 & 493 & 497 & 325 & 300 & 176 & 366 & 335 & 194 & 164 \\
\hline
\end{tabular}

*данные по ЖКХ за 2001 г.; составлено на основе данных сборников Росстата «Регионы России. Социально-экономические показатели».

27 Наиболее удручающая ситуация в сельских районах, где преимущественно проживают коренные жители Севера, куда газ так и не подведен (за редким исключением). 
Также сокращается и число детей, отдыхающих в детских оздоровительных учреждениях Севера. Некогда обширная инфраструктура детских лагерей, столь необходимая сегодня, учитывая снижение возможностей семей выезда в южные регионы и уменьшение дотаций предприятий в организации отдыха детей северян, сжимается. Образовательная инфраструктура на Севере тоже занимает отстающие позиции: выше становится доля детей, обучающихся в две смены, а удельный вес студентов сократился почти вдвое по сравнению с Россией в целом. Более низкое качество образовательных услуг можно оценить, сравнив средние баллы единого государственного экзамена по субъектам РФ, где школьники из большинства северных регионов (особенно дальневосточных) показывают низкие результаты ${ }^{28}$. Несколько лучше выглядит ситуация в медицине: мощность амбулаторно-поликлинических организаций на Севере выше, что связано с пониженными нормативами численности прикрепленного населения на врачебных участках ${ }^{29}$, учитывающими отдаленность населенных пунктов. Тем не менее уровень заболеваемости в северных регионах на четверть выше среднего по стране, что свидетельствует о более низком качестве предоставляемых услуг.

Рейтинг российских регионов по качеству жизни демонстрирует степень социального неравенства в пространстве, в котором богатый Север занимает далеко не первые строчки, отведенные жителям Москвы, Санкт-Петербурга, Московской и Ленинградской областей, Республики Татарстан, Белгородской области и Краснодарского края ${ }^{30}$, куда так стремятся северяне ${ }^{31}$. Замыкает рейтинг Республика Тыва с самым низким рейтинговым баллом качества жизни 13,96 против наивысшего 76,92 в Москве. Ханты-Мансийский АО, отдающий 24,7\% налоговых поступлений в федеральный бюджет, находится на 9-м месте; при высоких доходах населения Ямало-Ненецкого округа рейтинговый балл составляет 53,30 (16-е место). В остальных регионах Севера ситуация существенно хуже: Чукотский АО занимает лишь 78-е место, Архангельская область - 74-е, Якутия - 71-е, Карелия - 70-е, Ненецкий $\mathrm{AO}-67-e$, Коми - 65-е, и очевидных предпосылок для повышения качества жизни северян в ближайшей перспективе не наблюдается.

\section{Заключение}

В статье развивается концепция вытеснения применительно к северным регионам Российской Федерации и доказывается, что в результате неолиберальной политики созданы институты, оправдывающие социальное исключение северян. Население северных регионов России за последние годы лишилось существенной части своих преимуществ - высоких заработных плат, качественной инженерной и соци-

\footnotetext{
28 ЕГЭ: история изменений и баллы (2017) // Институт образования НИУ ВШЭ. 30 мая 2017 // https://ioe.hse.ru/lepa/news/206293596.html

29 Приказ Минздрава «Об утверждении положения об организации оказания первичной медико-санитарной помощи взрослому населению» (2018)//Consultant.ru // http://www.consultant.ru/document/cons_doc_LAW_132071/

30 Рейтинг российских регионов по качеству жизни-2017 (2018) // РИА Рейтинг. 14 февраля 2018 // http://riarating.ru/infografika/20180214/630082471.html

31 В 2015-2017 гг. треть покинувших Север (226 тыс. чел.) приходится именно на эти семь регионов.
} 
альной инфраструктуры. В настоящее время качество жизни на Севере уступает среднероссийскому по большинству рассмотренных показателей, и в наиболее сложной ситуации оказались жители сельских районов, работники сферы обслуживания и женщины.

Выравнивание заработных плат между регионами часто рассматривается как позитивный признак сокращения пространственного неравенства, однако в действительности с учетом специфики Севера (высоких цен, природных условий и удаленности) это снижает его привлекательность для жизни. С 1990 по 2018 г. Север России покинули 2,3 млн чел., или 24\% населения северных территорий РФ. В подавляющем большинстве городов и районов отток продолжается и сегодня: уезжают наиболее активная молодежь и высококвалифицированные кадры. В результате уровень человеческого капитала и интеллектуальный потенциал территории снижаются, в то время как социальная нагрузка в связи со старением населения растет. Учитывая, что российский Север, несмотря на высокие запасы природных ресурсов и экспортоориентированную экономику, не имеет возможностей для социально-экономического развития территории и защиты интересов северян, массовый отток населения можно рассматривать как социальный протест (форму молчаливого сопротивления на ухудшение условий жизни) против характерных для Севера социальных реалий.

На наш взгляд, выравнивание территориального развития, на что ориентирована политика Всемирного Банка, должно происходить благодаря наращиванию конкурентных преимуществ и развитию инновационной активности экономик более «слабых» регионов, а не за счет «проедания» доходов, получаемых от добычи природных ресурсов Севера. При этом сам Север должен иметь финансовую самостоятельность и возможности продвижения альтернативных способов решения проблем территории, но в нынешних условиях выравнивание регионов приводит к их вытеснению.

\section{Литература}

Барсукова С.Ю. (2004) Неформальная экономика: экономико-социологический анализ. М.: ВШЭ.

Замятина Н.Ю., Гончаров Р.В. (2017) Феномен урбанизации в комплексном развитии Арктической зоны // Управление инновационным развитием Арктической зоны РФ. Архангельск: КИРА. С. 167-172.

Зубаревич Н.В. (2010) Регионы России: неравенство, кризис, модернизация. М.: Независимый институт социальной политики.

Зубаревич Н.В., Сафронов С.Г. (2013) Неравенство социально-экономического развития регионов и городов России 2000-х годов: рост или снижение? // Общественные науки и современность. № 6. С. 15-26.

Игнатова Н.М. (2009) Спецпереселенцы в Республике Коми в 1930-1950-е гг. Сыктывкар: Институт языка, литературы и истории Коми НЦ УрО РАН.

Кириллов В.М. (1999) История репрессий и правозащитное движение в России. Екатеринбург: УМЦ УПИ.

Козина И. (2009) Работающие матери // Полит.ру. 25 декабря 2009 // http://www.polit.ru/article/2009/12/25/kozina/

Кротов П.П. (1998) Симптомы «Голландской болезни», найдется ли лекарство? Возможности экономической стабилизации ресурсного региона // Республика Коми: власть, бизнес, политика. Сыктывкар. С. 8-30. 
Лыткина Т.С. (2005) Экономическое поведение «новых бедных» в условиях социальной трансформации // дис. ... канд. социол. наук. М.

Лыткина Т.С. (2011) Социальная биография исключения в постсоветской России // Журнал социологии и социальной антропологии. № 1. С. 87-109.

Лыткина Т.С. (1) (2014) Социальный потенциал северного города: от игнорирования к признанию // Журнал социологии и социальной антропологии. № 3. С. 33-47.

Лыткина Т.С. (2) (2014) Человек на Севере после распада СССР: от признания к игнорированию // Известия Коми НЦ УрО РАН. № 3. С. 144-151.

Лыткина Т.С., Фаузер В.В. (2016) Государственное управление принудительной миграцией как способ освоения Севера России в 1930-1950-е гг. // Журнал социологии и социальной антропологии. №1. С. 90-109.

Лыткина Т.С., Ярошенко С.С. (2019) Возможна ли социология для трудящихся классов сегодня? // Мир России. № 1. С. 101-123.

Мальцева И.О., Рощин С.Ю. (2007) Гендерная сегрегация и трудовая мобильность на российском рынке труда. М.: ВШЭ.

Мезенцева Е.Б. (2001) Теоретические подходы к гендерной экономике // Воронина О.А. (ред.) Теория и методология гендерных исследований. М.: МЦГИ, МВШСЭН, МФФ. С. 109-184.

Милохин Д.В., Сметанин А.Ф. (2005) Коми колхозная деревня в послевоенные годы, 1946-1958: социально-экономические аспекты развития. М.: Наука.

Овчарова Л.Н. (2001) Бедность в России // Мир России. № 1. С. 171-178.

Овчарова Л.Н., Попова О.Д. (2013) Доходы и расходы российских домашних хозяйств: что изменилось в массовом стандарте потребления // Мир России. № 3. С. 3-34.

Преодоление пространственного неравенства. Как снова собрать советский «пазл» в условиях рыночной экономики (2018) // Всемирный банк. Май 2018 // http://documents.worldbank. org/curated/en/708911528099174034/pdf/126805-WP-REVISED-RUSSIAN-PUBLIC.pdf

Сен А. (2004) Развитие как свобода. М: Новое издательство.

Сен А. (2016) Идея справедливости. М.: Издательство Института Гайдара.

Стиглиц Дж. (2016) Великое разделение. Неравенство в обществе, или что делать оставшимся 99\% населения? М.: ЭКСМО.

Стыров М. (2012) Экстерриториальность финансового капитала промышленности: угрозы безопасности Севера России (По материалам Республики Коми) // Материалы VII северного социально-экологического конгресса. М.: Первая оперативная типография. С. 302-307.

Хасбулатова О.А. (2001) Российская государственная политика в отношении женщин (1900-2000) // Воронина О.А. (ред.) Теория и методология гендерных исследований. М.: МЦГИ, МВШСЭН, МФФ. С. 185-198.

Фаузер В.В. (2015) Демографические проблемы северных регионов России: сокращение численности населения и снижение рождаемости // Корпоративное управление и инновационное развитие экономики Севера: Вестник НИЦ КПУВИ СыктГУ. №1. С. $129-144$.

Юшков А., Одинг Н., Савулькин Л. (2017) Судьбы российских регионов-доноров // Вопросы экономики. № 9. С. 63-82.

Якоб В.В. (2012) Крестьянство Коми АО в период НЭПа, индустриализации, коллективизации (1920-1930-е гг.). Екатеринбург: РИО УрО.

Ярошенко С.С. (2005) Бедность в постсоциалистической России. Сыктывкар: Коми НЦ УpO PAH.

Burawoy M. (1996) The State and Economic Involution: Russia Through a China Lens // World development, vol. 24, no 6, pp. 1105-1117.

Chetvernina T. (1995) Minimum Wages in Russia: Fantasy Chasing Fact // Minimum Wages in Central and Eastern Europe: From Protection to Destitution (eds. Standing G., VaughanWhitehead D.), Budapest: Central European University press, pp. 49-67.

Galasi P., Sik E. (1998) Invisible Incomes in Hungary // Social Justice, vol. 15, no 3/4 (33-34), pp. $160-178$.

Sassen S. (2014) Expulsions: Brutality and Complexity in the Global Economy, Cambridge, MA: Belknap Press. 
Scott A., Storper M. (2014) The Nature of Cities: The Scope and Limits of Urban Theory // International Journal of Urban and Regional Research, vol. 39, no 1, pp. 1-15.

Wright E.O. (1994) Interrogating Inequality. Essays on Class Analysis, Socialism and Marxism, London, New York: Verso.

\title{
The Russian North \\ in the Context of Global Neoliberal Politics: Overcoming Spatial Inequality or Expulsion?
}

\author{
T. LYTKINA*, A. SMIRNOV**
}

\begin{abstract}
*Tatyana Lytkina - PhD in Sociology, Senior Researcher, Institute of Social, Economic and Energy Problems of the North of the Komi Science Centre, Ural Branch of the Russian Academy of Sciences. Address: 26, Kommunisticheskaya St., Syktyvkar, 167982, Russian Federation. E-mail: tlytkina@yandex.ru

**Andrey Smirnov - PhD in Economics, Researcher, Institute of Social, Economic and Energy Problems of the North of the Komi Science Centre, Ural Branch of the Russian Academy of Sciences. Address: 26, Kommunisticheskaya St., Syktyvkar, 167982, Russian Federation. E-mail: av.smirnov.ru@gmail.com
\end{abstract}

Citation: Lytkina T., Smirnov A. (2019) The Russian North in the Context of Global Neoliberal Politics: Overcoming Spatial Inequality or Expulsion. Mir Rossii, vol. 28, no 3, pp. 27-47 (in Russian). DOI: 10.17323/1811-038X-2019-28-3-27-47

\begin{abstract}
In this article, based on official statistics 2000-2017, we argue that neoliberal policies have neglected the Russian North: its people, its enterprises and its territories have been expelled from core social and economic processes. We develop the concept of "expulsion" to argue that organized institutional exclusion is the result of mischaracterizing Northern welfare, intensifying the structures of inequality, and the extensive use of infrastructure. This has led to a decrease in the level and the quality of Northern life. Only a small fraction of them have high incomes, and even these incomes no longer compensate for the costs associated with working in a harsh climate with high costs of living. We show that the infrastructure built during the Soviet era is deteriorating, and the quality of healthcare and education is declining. The market mechanism has destroyed former social guarantees as well as undermined any long-term development strategy - a development strategy that would maintain living standards corresponding to the contribution of the Northern Regions to the GNP and the Federal Budget. Furthermore, economic expulsion has increased the number of socially vulnerable groups and intensified resource dependence. In other words, we cannot explain the impoverishment of the North in terms of the theory of "competitive advantage" but rather it is due to systematic expulsion of a region with high economic potential.
\end{abstract}


Key words: inequality, expulsion, exclusion, poverty, North, post-Soviet Russia, post-socialism

\section{References}

Barsukova S.Yu. (2004) Neformalnaya ekonomika: ekonomiko-sotsiologicheskiy analiz [Informal Economy: Economic and Sociological Analysis], Moscow: HSE.

Burawoy M. (1996) The State and Economic Involution: Russia Through a China Lens. World Development, vol. 24, no 6, pp. 1105-1117.

Chetvernina T. (1995) Minimum Wages in Russia: Fantasy Chasing Fact. Minimum Wages in Central and Eastern Europe: from Protection to Destitution (eds. Standing G., Vaughan-Whitehead D.), Budapest: Central European University press, pp. 49-67.

Fauzer V.V. (2015) Demograficheskie problemy severnykh regionov Rossii: sokrashchenie chislennosti naseleniya i snizhenie rozhdaemosti [The Demographic Problems of Russian Northern Regions: the Declines of Population and Fertility]. Korporativnoe upravlenie $i$ innovatsionnoe razvitie ekonomiki Severa: Vestnik NITS KPUVI SyktGU, no 1, pp. 129-144.

Galasi P., Sik E. (1998) Invisible Incomes in Hungary. Social Justice, vol. 15, no 3/4 (33-34), pp. $160-178$.

Ignatova N.M. (2009) Spetspereselentsy v Respublike Komi v 1930-1950-e gg. [Special Immigrants in the Komi Republic in the 1930-1950s], Syktyvkar: UrO RAN.

Khasbulatova O.A. (2001) Rossijskaya gosudarstvennaya politika v otnoshenii zhenshchin (1900-2000) [The Russian State Policy on Women (1900-2000)]. Teoriya i metodologiya gendernykh issledovanij [Theory and Methodology of Gender Studies] (ed. Voronina O.F.), Moscow: MTSGI, MVSHSEN, MFF, pp. 185-198.

Kirillov V.M. (1999) Istoriya repressij i pravozashchitnoe dvizhenie $v$ Rossii [The History of Repression and the Human Rights Movement in Russia], Yekaterinburg: Izd-vo UMTS UPI.

Kozina I.M. (2009) Rabotayushchie materi [Working Mothers]. Polit.ru, December 25, 2009. Available at: http://www.polit.ru/article/2009/12/25/kozina/, accessed 15.05.2019.

Krotov P.P. (1998) Simptomy «Gollandskoj bolezni», najdetsya li lekarstvo? Vozmozhnosti ekonomicheskoj stabilizatsii resursnogo regiona [The Symptoms of "the Dutch Disease" in Russia: Is There Any Remedy? Possibilities of Sustainable Development of a Resource Abundant Region]. Respublika Komi: vlast, biznes, politika [Komi Republic: Power, Business, Politics], Syktyvkar, pp. 8-30.

Lytkina T.S. (2005) Ekonomicheskoe povedenie «novykh bednykh» v usloviyakh sotsialnoj transformatsii [The Economic Behaviour of "the New Poor" During Social Transformation], dissertation, Moscow.

Lytkina T.S. (2011) Sotsial'naya biografiya isklyucheniya v postsovetskoj Rossii [The Biography of Social Exclusion in Post-Soviet Russia]. Zhurnal sotsiologii i sotsial'noj antropologii, no 1, pp. 87-109.

Lytkina T.S. (1) (2014) Sotsialnyj potentsial severnogo goroda: ot ignorirovaniya k priznaniyu [The Social Potential of the Northern City: from Ignorance to Recognition]. Zhurnal sotsiologii $i$ sotsial'noj antropologii, no 3, pp. 33-47.

Lytkina T.S. (2) (2014) Chelovek na Severe posle raspada SSSR: ot priznaniya k ignorirovaniyu [Man in the North after the Disintegration of USSR: from Recognition to Ignorance]. Izvestiya Komi NTS UrO RAN, no 3, pp. 144-151.

Lytkina T.S., Fauzer V.V. (2016) Gosudarstvennoe upravlenie prinuditelnoj migratsiej kak sposob osvoeniya Severa Rossii v 1930-1950-e gg. [Forced Migration as a Way of Developing the Russian North in the 1930s-1950s]. Zhurnal sotsiologii $i$ sotsial'noj antropologii, no 1, pp. 90-109.

Lytkina T.S., Yaroshenko S.S. (2019) Vozmozhna li sotsiologiya dlya trudyashchihsya klassov segodnya? [Is Sociology for the Working Classes Possible Today?]. Mir Rossii, no 1, pp. $101-123$. 
Maltseva I.O., Roshchin S.Yu. (2007) Gendernaya segregatsiya i trudovaya mobilnost na rossiyskom rynke truda [Gender Segregation and Labor Mobility in the Russian Labor Market], Moscow: HSE.

Mezentseva E.B. (2001) Teoreticheskie podkhody $\mathrm{k}$ gendernoj ekonomike [Theoretical Approaches to Gender Economics]. Teoriya $i$ metodologiya gendernykh issledovanij [Theory and Methodology of Gender Studies] (ed. Voronina O.F.), Moscow: MTSGI, MVSHSEN, MFF, pp.

Milokhin D.V., Smetanin A.F. (2005) Komi kolhoznaya derevnya v poslevoennye gody, 1946-1958: sotsial'no-ekonomicheskie aspekty razvitiya [Komi Collective Farm Village in the Postwar Years, 1946-1958: the Socio-economic Aspects of Development], Moscow: Nauka.

Ovcharova L.N. (2001) Bednost' v Rossii [Poverty in Russia]. Mir Rossii, no 1, pp. 171-178.

Ovcharova L.N., Popova O.D. (2013) Dokhody i raskhody rossijskih domashnikh khozyajstv: chto izmenilos' v massovom standarte potrebleniya [Cash Income and Expenditure of the Russian Population: What Are the Changes in Consumer's Standard]. Mir Rossi, no 3, pp. 3-34.

Preodolenie prostranstvennogo neravenstva. Kak snova sobrat' sovetskij «pazl» v usloviyakh rynochnoj ekonomiki [Overcoming Spatial Inequalities: How to Reassemble the Soviet Puzzle in the Conditions of Market Economy] (2018). World Bank, May, 2018. Available at: http://documents.worldbank.org/curated/en/708911528099174034/pdf/126805-WPREVISED-RUSSIAN-PUBLIC.pdf, accessed 15.05/2019.

Sassen S. (2014) Expulsions: Brutality and Complexity in the Global Economy, Cambridge, MA: Belknap Press.

Scott A., Storper M. (2014) The Nature of Cities: The Scope and Limits of Urban Theory. International Journal of Urban and Regional Research, vol. 39, no 1, pp. 1-15.

Sen A. (2004) Razvitie kak svoboda [Development as Freedom], Moscow: Novoe izdatel'stvo.

Sen A. (2016) Ideya spravedlivosti [The Idea of Justice], Moscow: Izdatelstvo Instituta Gaydara.

Stiglitz J. (2016) Velikoe razdelenie. Neravenstvo $v$ obshchestve, ili chto delat' ostavshimsya 99\% naseleniya? [The Great Divide: Unequal Societies and What We Can Do About Them], Moscow: Eksmo.

Styrov M. (2012) Eksterritorialnost' finansovogo kapitala promyshlennosti: ugrozy bezopasnosti Severa Rossii (Po materialam Respubliki Komi) [The Extraterritoriality of Industrial Financial Capital: Threats to the Security of the Russian North (Based on the Case of the Komi Republic)]. Materialy VII severnogo sotsial'no-ekologicheskogo kongressa [The Proceedings of the VII Nordic Socio-ecological Congress], Moscow: Pervaya operativnaya tipografiya. pp. 302-307.

Wright E.O. (1994) Interrogating Inequality. Essays on Class Analysis, Socialism and Marxism, London, New York: Verso.

Yakob V.V. (2012) Krestyanstvo Komi AO v period NEPa, industrializatsii, kollektivizatsii (1920-1930-e gg.) [The Peasantry of the Komi AO During the Period of NEP, Industrialization, Collectivization (1920-1930s)], Yekaterinburg: RIO UrO.

Yaroshenko S.S. (2005) Bednost'v postsotsialisticheskoj Rossii [Poverty in post-Socialist Russia], Syktyvkar: Komi NTS UrO RAN.

Yushkov A., Oding N., Savulkin L. (2017) Sud'by rossijskikh regionov-donorov [The Trajectories of Donor Regions in Russia]. Voprosy ekonomiki, no 9, pp. 63-82.

Zamyatina N.Yu., Goncharov R.V. (2017) Fenomen urbanizatsii v kompleksnom razvitii Arkticheskoy zony [The Phenomenon of Urbanization in the Integrated Development of the Arctic Zone]. Upravlenie innovatsionnym razvitiem Arkticheskoj zony $R F$ [The Management of Innovative Development of the Arctic Zone of RF], Arkhangelsk: KIRA, pp. 167-172.

Zubarevich N.V. (2010) Regiony Rossii: neravenstvo, krizis, modernizatsiya [The Regions of Russia: Inequality, Crisis, Modernization], Moscow: Independent Institute for Social Policy.

Zubarevich N.V., Safronov S.G. (2013) Neravenstvo sotsial'no-ekonomicheskogo razvitiya regionov i gorodov Rossii 2000-h godov: rost ili snizhenie? [The Inequality of Social and Economic Development of Regions and Cities of Russia of the 2000s: Growth or Decline?]. Obshchestvennye nauki i sovremennost', no 6, pp. 15-26. 